How to cite: Milian, N. (2019) 2017-2018 Winter - Favorable Avalanche Conditions in Southern Carpathians. 2019 "Air and Water - Components of the Environment" Conference Proceedings, Cluj-Napoca, Romania, p. 399406, DOI: $10.24193 /$ AWC2019 39.

\title{
2017-2018 WINTER - FAVORABLE AVALANCHE CONDITIONS IN SOUTHERN CARPATHIANS
}

\author{
Narcisa MILIAN $N^{I}$ \\ DOI: 10.24193/AWC201939
}

\begin{abstract}
The paper presents and analyzes the variations of the measured parameters at the meteorological stations, favoring the avalanches of the winter season 2017-2018 in the areas monitored by Romanian National Administration of Meteorology. The analyzed parameters, both meteorological and snow specific, are measured in daily observations and weekly measurements at Bâlea-Lac, Vârfu-Omu, Sinaia and Predeal meteorological stations, since February 2004. Annual reports include studies about the evolution of avalanche risk during winters (***, Bilanţul nivologic al sezonului de iarnă, 2011-2017). Every year, the favorable conditions leading to avalanche triggering were analyzed (Milian,2015; Grecu C. \& al. 2016; Milian, 2016; Reckerth \& al,2018). All measured and observed data, as well as are included in a database to study conditions favorable to avalanche triggering and its use to better estimate avalanche risk and mitigate its environmental and human impacts (Esteban P. $\&$ al, 2005). First snowfalls have fallen at 7 October 2017, forming a first snow layer, that melted days after. A new continuous snow layer was formed after 24 October 2017 at VârfuOmu and at all other mountainous stations after 28 November. The snow has maintained in the upper areas of Bucegi and Făgăraş Mountains until 17 May 2018 at Bâlea-Lac and May 22, 2018 at Vârfu-Omu. Avalanche triggering conditions were due most to high temperatures and/ or sudden temperature growth, and less to significant snowfalls and conditions occurring within the snow layer, resulting of unstable structures.
\end{abstract}

Keywords: avalanche, ground pressure, temperature, snowfall, Southern Carpathians

\section{INTRODUCTION}

Nivological season 2017-2018 began on October 6, 2017 at all four stations that perform a nivological program. During the year 2018, 990 observations were made at the meteorological stations already included in the nivological program (Sinaia, Predeal, Vârfu-Omu and Bâlea-Lac), twice daily, starting 1 January and 15 April in Predeal and Sinaia, 15 May at Bâlea-Lac and 31 May at Vârfu-Omu. At these stations, 92 surveys and stratigraphic profiles of the snow layer were made. Last nivological information was issued on May 3. The newsletters were posted on the official site of the National Meteorological Administration and sent to: Dispatcher of the Ministry of Environment, Mountain Rescue Teams (Salvamont), prefectures,

\footnotetext{
${ }^{1}$ SRPV Sibiu, CMR Transilvania-Sud, 550003 Sibiu, Romania; Phd Student at Şcoala Doctorală de Ştiințe, Craiova University, Romania narcisa.milian@gmail.com
} 
county councils in the monitored area, mass media.

Annual schedule of daily meteorological parameters show snow thickness variation, as well as alternation of colder with warmer periods, that favored partial snow melting and surface moisture, thus increasing the risk of triggering avalanches (Fig. 1).

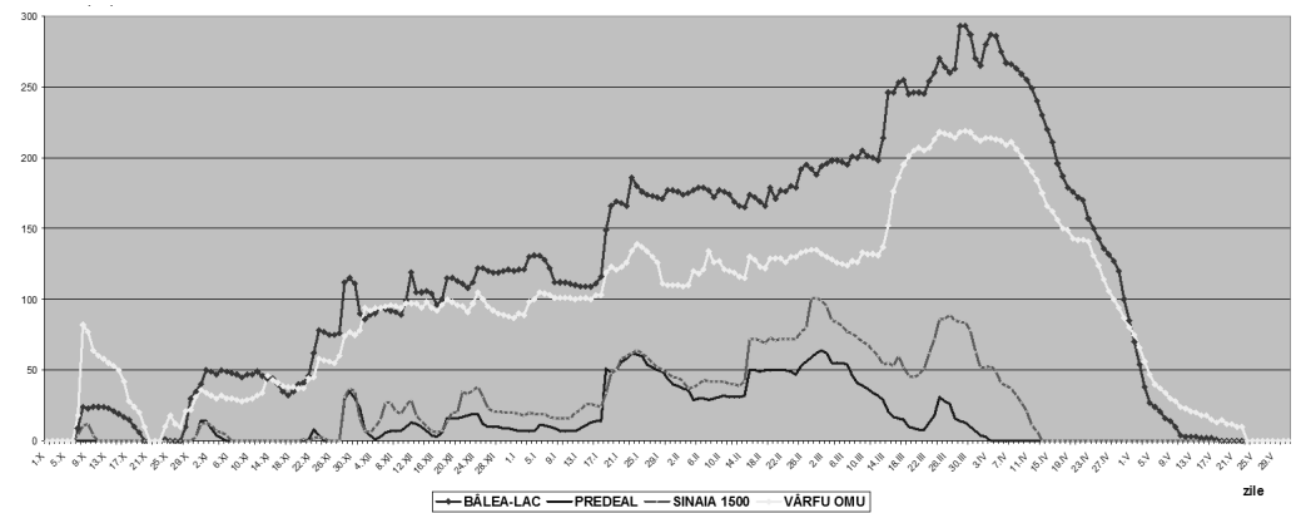

Fig. 1. 2017-2018 winter season - daily meteorological parameters measured at the four meteorological stations with nivologic programm

Maximum snow thickness in the meteorological stations platform were recorded at Bâlea-Lac on 28 March, 2018 and had the value of $294 \mathrm{~cm}$. At the other stations, the highest values were: $219 \mathrm{~cm}$ at Vârfu-Omu (28-29.03.2018), $102 \mathrm{~cm}$ at Sinaia (28.02.2018) and $64 \mathrm{~cm}$ at Predeal (01.03.2018) (Fig.1).

\section{SYNOPTIC CONDITIONS FOR AVALANCHE PERIODS}

\subsection{November $11-22,2017$}

During the period, the Icelandic Trough was active over the country, except 1417 November, when Azores High influenced our area; at 500 hpa, the associated Icelandic Trough was active most of the time (Fig. 2). At the level of $850 \mathrm{hPa}$, isotherm value ranged from 2 to $6{ }^{\circ} \mathrm{C}$ from 11 to 18 November, then decreased to $6 \ldots-4{ }^{\circ} \mathrm{C}$ until 21 November, increasing again on last day of the interval, to $1{ }^{\circ} \mathrm{C}$.
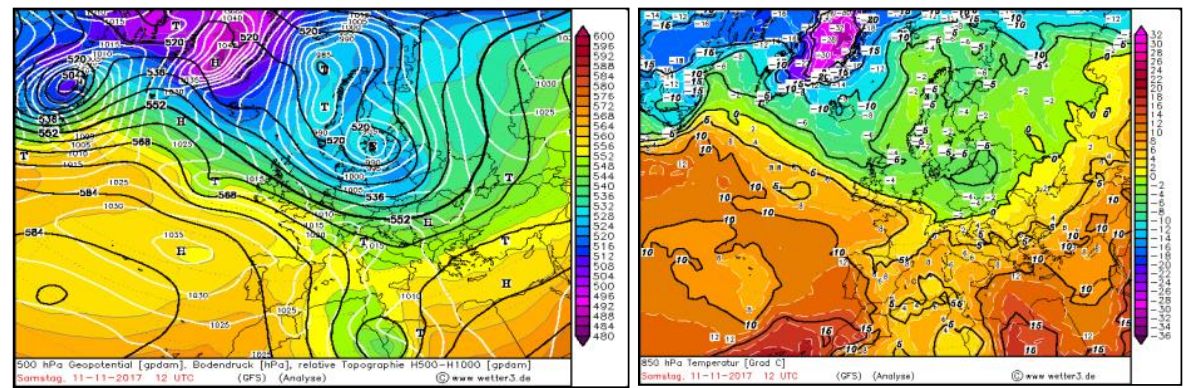

Fig. 2. 2017.11.11, at 12 UTC-NCEP numerical model-reanalysis.

Ground-level pressure, relative topography, geopotential, 850 hPa temperature 
Maximum temperatures increased, becoming positive at altitudes of $2000 \mathrm{~m} \mathrm{-} \mathrm{at}$ the Bâlea-Lac meteorological station $\left(0.4 \ldots 4.1^{\circ} \mathrm{C}\right)$, and minimum ones also had high values (reaching $1.3{ }^{\circ} \mathrm{C}$ ).

Even at $2500 \mathrm{~m}$ - Vârfu-Omu meteorological station - maximum temperatures have reached values of $0 \ldots 1,2{ }^{\circ} \mathrm{C}$ for three consecutive days. Temperature values have also been high in the previous period, favouring snow wetting at the surface and triggering wet snow avalanches.

\subsection{January 5 to 7,2018}

At the beginning, Icelandic Low was active over Romania, then, from January 6, Europe High advanced over our country, with correspondent structure on altitude, increasing ground pressure to $1020 \mathrm{hPa}$ and geopotential values at $500 \mathrm{hPa}$ from 552 to 568 dmgp. (Fig. 3).

Temperatures during the day increased to positive values even on higher altitude, for example $3,5^{\circ} \mathrm{C}$ at Bâlea-Lac, where snow decreased from 131 to $118 \mathrm{~cm}$. Melting surface avalanches happened every day.
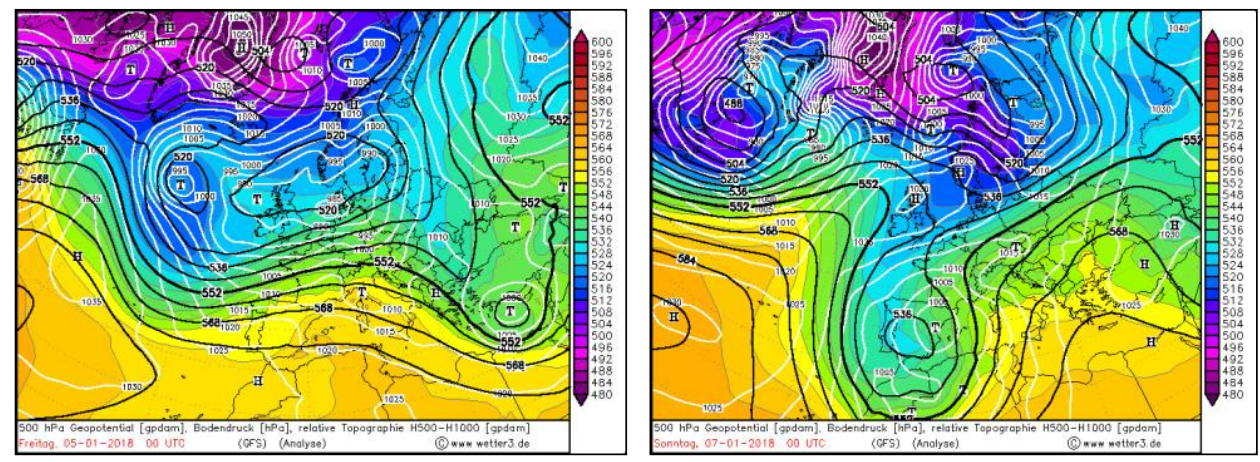

Fig. 3. 2018.01.05 and 07, a t00 UTC - NCEP numerical model reanalysis. Ground-level pressure, relative topography, geopotential, 850 hPa temperature

\subsection{January 16 to 24,2018}

The period was dominated by widening of Icelandic Trough from 17 to 22 January, with ground pressure values of $1010 \mathrm{hPa}$ and intrusion of East European High from 23 and 24 January. In middle troposphere, the associated Icelandic Trough persisted until the last day, when associated Azores Ridge gradually moved over Romania (Fig. 4).

The values of $850 \mathrm{hPa}$ level isotherm highly increased from January 16 at 00 hour $\left(-10{ }^{\circ} \mathrm{C}\right)$ to $-5 \ldots-4{ }^{\circ} \mathrm{C}$ at noon and remained at that value until the end of the interval.

Temperatures were low, up to $-13.4{ }^{\circ} \mathrm{C}$ at Bâlea-Lac and -17.3 at Vârfu Omu. Snow layer increased from 103 to $139 \mathrm{~cm}$ at Vârfu-Omu and from 111 to $186 \mathrm{~cm}$ at Bâlea-Lac. Several fresh, light snow avalanches were recorded. 

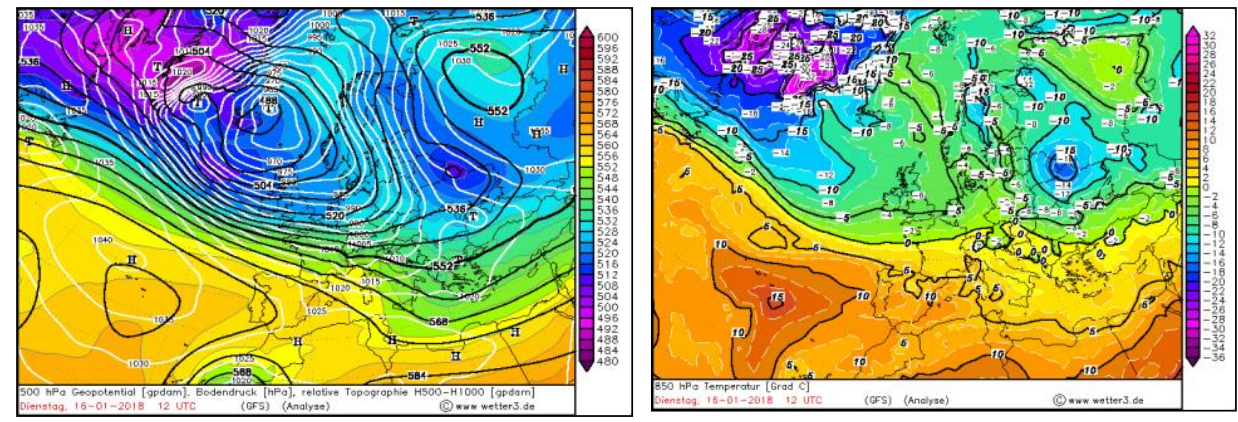

Fig. 4. 2018.01.16, at 12 UTC - NCEP numerical model reanalysis. Ground-level pressure, relative topography, 500hPa geopotential, 850 hPa temperature

\subsection{April 3-4, 2018}

Ground pressure field was high, due to the Azores Ridge, with values of $1020 \ldots 1025 \mathrm{hPa}$, and also on middle troposphere (up to $568 \mathrm{dmgp}$ ). Isotherm at 850 $\mathrm{hPa}$ level had positive values, from 5 to $10^{\circ} \mathrm{C}$ (Fig. 5).

Maximum temperatures were positive at all meteorological stations. Snow melted from 287 to $275 \mathrm{~cm}$ at Bâlea-Lac, and melting avalanches were observed.
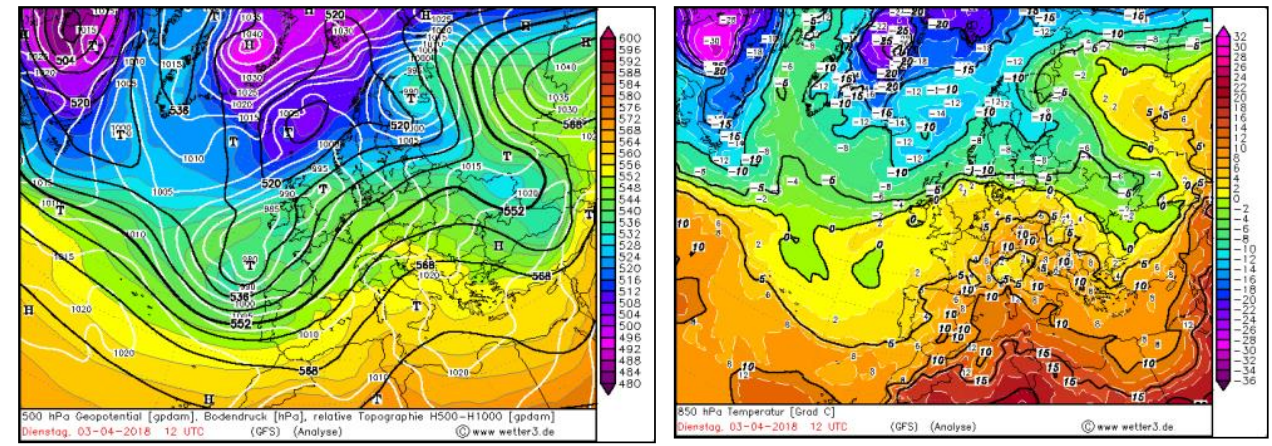

Fig. 5. 2018.04.03, at 12 UTC-NCEP numerical model-reanalysis. Ground-level pressure, relative topography, geopotential, 850 hPa temperature

\subsection{April 7 to 10, 2018}

The period was characterized by the presence of the Icelandic Trough and advance of a Mediterranean Low to south and then east of the country.

Frontal systems were active in western Romania from March 22 to 27, together with Icelandic Low descent, then an occluded front over the country up to March 30. On middle troposphere, an associated Icelandic Trough was also active (Fig. 6).

Maximum temperatures were positive at all meteorological stations, even the high ones (over $2000 \mathrm{~m}$ ). Snow melted from 266 to $253 \mathrm{~cm}$ at Bâlea-Lac, and from 211 to $193 \mathrm{~cm}$ at Vârfu-Omu. Daily melting avalanche occurred. 

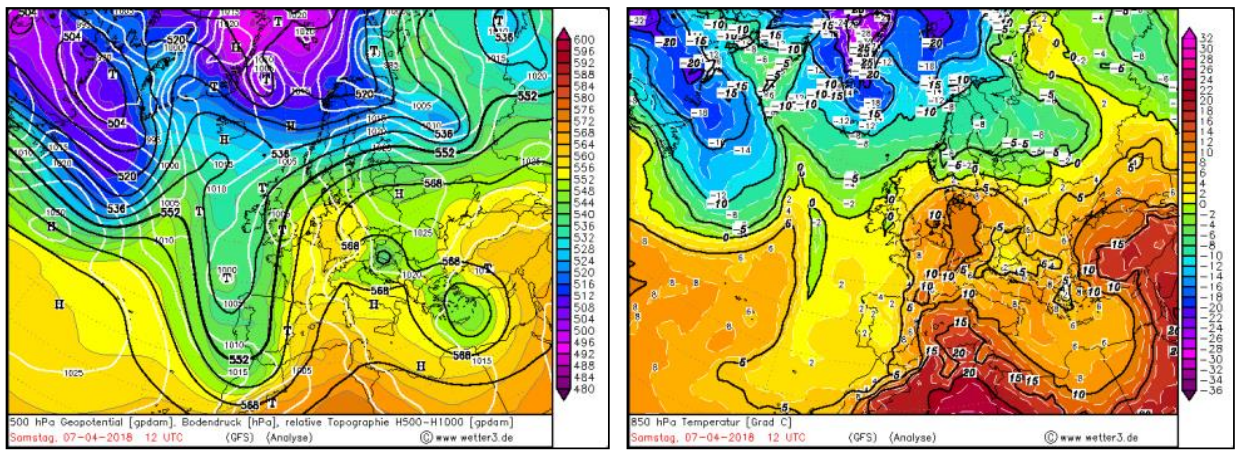

Fig. 6. 2018.04.07 and 10, at 12 UTC-NCEP numerical model-reanalysis. Ground-level pressure, relative topography, geopotential, 850 hPa temperature

\subsection{April 13 to 18, 2018}

Until the end of this period, the Azores Ridge persisted over the country, with ground pressure field values from 1025 to $1015 \mathrm{hPa}$ on last day. In the middle troposphere, the associated Azores Ridge also persisted over the country, with geopotential values around $568 \mathrm{dmgp}$. In lower troposphere, the $850 \mathrm{hPa}$ isotherm had high values, of $10 \ldots 12{ }^{\circ} \mathrm{C}$, than fell to $8^{\circ} \mathrm{C}$ (on April 18) (Fig. 7).

Daytime temperatures recorded at all meterological stations were positive, reaching $10.6{ }^{\circ} \mathrm{C}$ at Bâlea-Lac, and $8.2^{\circ} \mathrm{C}$ at Vârfu-Omu. Night temperatures were negative at altitudes above $2000 \mathrm{~m}$ and positive at lower altitudes. Snow melted fast, from 230 to $176 \mathrm{~cm}$ at Bâlea-Lac and from 175 to $147 \mathrm{~cm}$ at Vârfu-Omu. Melting avalanches were recorded almost every day.
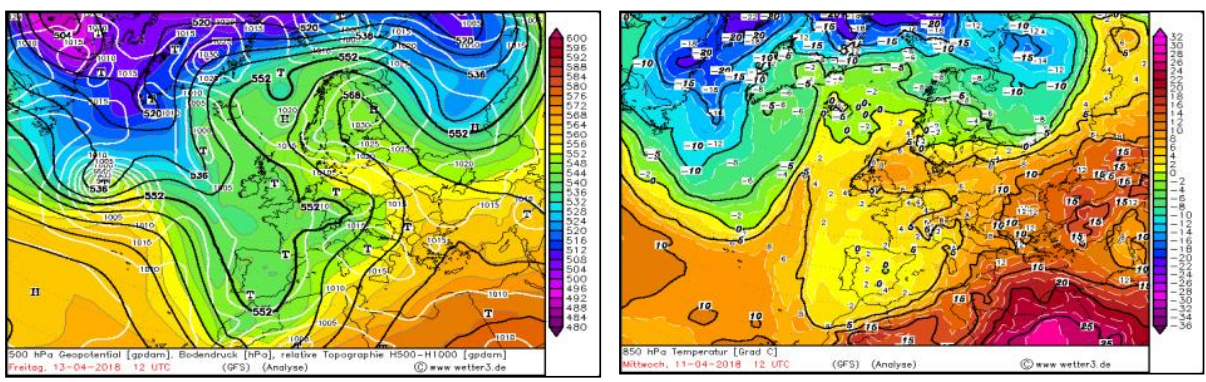

Fig. 7. 2018.04.13, at 12 UTC-NCEP numerical model-reanalysis. Ground-level pressure, relative topography, geopotential, 850 hPa temperature

\section{CONCLUSIONS}

Avalanches during 2017-2018 winter occured under different synoptic conditions and in every month. Important snowfall, sudden increasing temperatures and southern winds were the most common avalanche triggering conditions, but also snow crystals transformations within the layer, especially the presence of faceted, unstable crystals inside. Important snowfalls, sudden warming and wind intensification from southern 
sector were predicted in daily meteorological bulletins (***, Buletinul nivometeorologic), while crystal transformations were predicted by specific software.

Because of the variety of conditions that can lead to instability of snow, every risk situations should be studied, in order to create a pattern of avalanche danger (Green et al. 2006), as well as a climatology of major avalanche winters (Fitzharris B.B., 1987). New observations points all over Carpathian Mountains will increase the data for avalanche risk estimations in the affected areas, in order to prevent and avoid any human life loss, massive accidents with significant economic damage.

From the six studied periods, four were under the effect of Icelandic Depression, and only two of the Azores Ridge.

During 2017-2018 winter, most of the avalanches happened on a low-pressure system at ground levels, associated with a trough in higher altitudes, most because of high thermal values and transformations that occur within the snow, leading to unstable structures and less in case of significant snowfall.

\section{REFERENCES}

1. Esteban P. \& al, (2005), Atmospheric circulation patterns related to heavy snowfall days in Andorra, Pyrenees, International Journal of Climatology, 25, 3, 319-329.

2. Fitzharris B.B., (1987), A climatology of major avalanche winters in Western Canada, , Atmosphere-Ocean, 25: 2, 115-136.

3. Greene E., Wiesinger T., Birkeland K., Coléou C., Jones A., Statham G. (2006), Fatal avalanche accidents and forecasted danger levels: Patterns in the United States, Canada, Switzerland and France, ISSW

4. Hansen C., Underwood S.J, (2012), Synoptic Scale Weather Patterns and Size-5 Avalanches on Mt. Shasta, California, Northwest Science, 86, 329-341.

5. Höller P., (2009), Avalanche cycles in Austria: an analysis of the major events in the last 50 years, Natural Hazards, 48, 3, 399-424.

6. Jaedicke C., Bakkehøi S., (2007), Climate database for avalanche consulting and warning in Norway, Cold Regions Science and Technology, 47, 1-2, 171-179.

7. Milian N., Stăncescu M., Reckerth U., Variaţiile parametrilor nivometeorologici în cursul iernii 2015-2016, Sesiunea anuală de comunicări ştiinţifice, Administraţia Naţională de Meteorologie

8. Milian N., (2015), Synoptic Conditions for Avalanche Cases in Romania, Conferinţa Aerul şi Apa Componente ale Mediului, ISSN 2067-743X, DOI: 10.17378/AWC2015 40, 299-306.

9. Milian N., Paşol A., (2016), Synoptic Avalanche Triggering Conditions during 2014-2015 Winter, Conferinţa Aerul şi Apa Componente ale Mediului; DOI: 10.17378/AWC2016_39, 306-313.

10. Grecu C.L. et al. (2017), Synoptic Conditions Generating Important Snowfalls and Their Relation with Avalanches in 2015-2016 Wnter; Conferinţa Aerul şi Apa Componente ale Mediului; DOI: 10.24193/AWC2017_48, 379-386.

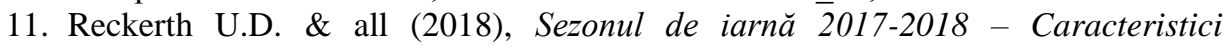
nivometeorologice, Sesiunea ştiinţifică anuală a Administraţiei Naţionake de Meteorologie 
12. ***, Bilanţul nivologic al sezonului de iarnă - publicaţie anuală, începând din 2004, Administraţia Naţională de Meteorologie, Bucureşti.

13. ***, Buletinul nivometeorologic - arhiva, Serviciul Regional de Prognoză a Vremii Sibiu.

14. http://www.wetter3.de, accesed on January 07, 2018. 
